\title{
LEARNING STYLES ACCORDING TO VARK CLASSIFICATION AND THEIR POSSIBLE USES IN TERTIARY EDUCATION CARRIED OUT IN THE FORM OF E-LEARNING
}

\author{
Milan KLEMENT; Jiř́ DOSTÁL
}

\begin{abstract}
Learning styles are important determinants of the use the electronic learning materials in education. These materials consist of many structural elements, of which some respect individual learning styles more and some less. In the realized research, the question has been solved of whether the particular components of electronic teaching materials are the same for different groups of students with respect to their individuality, which can be manifested by preferred learning styles. The course and some of the partial results of the realized research, focused on the use of learning styles in education realized in the form of e-learning, are presented in this study.
\end{abstract}

Key words: learning styles; electronic learning materials, structural elements; multimediality, interactivity, factor analysis, cluster analysis

\section{STYLY UČENÍ DLE KLASIFIKACE VARK A MOŽNOSTI JEJICH VYUŽITÍ VE VYSOKOŠKOLSKÉM VZDĚLÁVÁNÍ REALIZOVANÉM FORMOU E-LEARNINGU}

Resumé: Styly učení jsou determinantem využívání elektronických výukových materiálů ve vzdělávání. Tyto materiály se skládají z mnoha strukturálních prvkủ, lze předpokládat, že některé prvky více a některé méně odpovídají individuálním stylům učení. $\mathrm{V}$ rámci realizovaného výzkumného šetření byla řešena otázka, zda jednotlivé prvky elektronických výukových materiáli̊ pro e-learning jsou stejně potřebné pro různé skupiny studentů při respektování jejich individuality, která se projevuje preferovaným stylem učení dle klasifikace VARK. Průběh a některé dílčí výsledky realizovaného výzkumného šetření přestavuje předložená studie.

Klíčová slova: styly učení, klasifikace VARK, e-learning, elektronická studijní opora, strukturální prvky, multimedialita, interaktivita, faktorová analýza, shluková analýza

\section{1 Úvod}

„Styly učeni jsou definovány jako postupy při učeni, které jedinec $v$ určitém obdobi svého vývoje preferuje“ (Mareš, 1998). I když uvedená definice zní velmi jednoduše, setkáme se $\mathrm{v}$ odborné literatuře $\mathrm{s}$ mnoha typy vymezení tohoto pojmu (learning style, cognitive style, cognitev learning style), což L. Curryová výstižně označila ,jako zmatek v definicích“ (Curry, 1990). Jelikož by prezentace souvislostí mezi pojmy kognitivní styl, kognitivní styl učení a styl učení přesáhl rozsah této studie, odkazujeme na zevrubné pojednání o této problematice, které uvádí J. Mareš (Mareš, 1998). Většina autorů se shoduje, že základ jednotlivých stylů učení je s největší pravděpodobnosti vrozený, ale během života se záměrně i bezděčně mění vlivem nových zkušeností. Styly učení mají tedy charakter metastrategie, která seskupuje svébytné učební strategie, učební taktiky a učební operace.
Monitoruje je, vyhodnocuje, orientuje určitým směrem. Reguluje je s ohledem na podmínky učení, vlastní průběh učení, dosahované výsledky učení a s ohledem na sociální kontext učení. Styly učení vedou jedince $\mathrm{k}$ učebním výsledkům určitého typu, ale znesnadňují dosažení výsledků jiných. Člověk si své styly učení zpravidla neuvědomuje, systematicky je neanalyzuje, promyšleně je nezlepšuje (Mitchell, 1994). Svému nositeli se styly učení jeví jako postupy samozřejmé, běžné, navyklé, jemu vyhovující, v některých prípadech je chápe jako postupy pro něj optimální (Sak, Mareš, 2007).

Styl učení je charakterizován vrstvenou, „cibulovitou“ strukturou, kterou dle L. Curryové (Curry, 1990) tvoří osobnostní deskriptory, tendence ke zpracování informací a sociální vlivy. Americký autor J. C. Marshall (Marshall, 1987) pak tuto strukturu zpřesňuje a popisuje nejhlubší vrstvu jako nejstabilnější, nejméně 
ovlivnitelnou, střední vrstvu považuje za ovlivnitelnou dlouhodobým a cíleným působením, a svrchní vrstvu za málo stabilní, relativně snadno ovlivnitelnou učebním prostředím (Mareš, 1998). Výsledná kombinace těchto vrstev určuje žákovy preference způsobů učení (Šimonová et al., 2010). Vývojové hledisko je dále ovlivňováno vrozenými faktory, zvláště neuropsychickými mechanismy. Např. R. Dunnová (Dunn, 2003) studovala preference hemisfér a zjistila, že žáci s dominantní levou hemisférou upřednostňují tradiční učební prostředí, vizuální učení a strukturované obsahy, zatímco žáci s dominantní pravou hemisférou se raději učí ve skupině, se zvukovou kulisou (hudba), v neformálním prostředí, s netradičním nábytkem, dávají přednost taktilnímu učení a experimentovaní před učením auditivním, vizuálním, přesně strukturovaným (Šimonová et al., 2010). H. Gardner (Gardner, 1984) představil dodnes diskutovanou teorii mnohočetných inteligencí. V ní vymezil sedm různých druhů inteligence, které by měly mnohem lépe obsáhnout rozmanitost lidských schopností. V roce 1993 došel ve svých výzkumech k závěru, že studující bez rozdílu věku využívá rozdílné postupy při řešení určitých typů úkolů (Gardner, 1995). Vyšel tedy z předpokladu, že jedinec na základě svých schopností (jejich intenzity a způsobu fungování) reaguje odlišně na různé typy obsahů, popř. i ostatní jedince.

Jak uvádí I. Šimonová „definice stylu učeni vycházejici z jeho samotné podstaty, tj. odlišného, a prece správného pohledu na problém, vedly ke vzniku mnoha pojeti stylù učení. I když jednotlivé modely vykazuji některé shodné př̀stupy, byly vyvijeny na rüzných vědeckých pracovištich, bez vzájemné spolupráce autorü a jsou popsány odlišnou terminologiı ${ }^{\prime \prime}$. F. Coffield (Coffield et al., 2004) vybral podle kritéria důležitosti, rozšíŕenosti a vlivu na ostatní 71 stylů, z nichž sestavil následující skupiny (Šimonová et al., 2010):

- Model R. a K. Dunnových, který považuje styl poznávání a učení za stálý a velmi obtížně měnitelný, protože způsob poznáváni a učení se je dán geneticky (Dunn, 2003).

- Pojetí Witkina, Ridinga a Cheemaové, která vycházejí z teorie, že styly jsou obecné zvyky, trvalá, stabilní základna, ze které vychází chovaní jedince, a jako takové nepodléhají výchovně-vzdělávacím vlivům, nedochází $\mathrm{k}$ jejich změnám (Riding, Cheema, 1991).

- Model Briggsové a Myersové (Myers, Briggs, 1985), který vychází z Jungova pojetí osobnosti, kdy styl učení je chápán jako součást relativně stálého typu osobnosti, a je pozorovatelný z vnějšího prostředí (Coffield, F. et al., 2004).

- V pojetí Kolba (Kolb, 1984), Honeyho a Mumforda (Honey, Mumford, 2002), Feldera a Silvermana (Felder, Silverman, 1998) není styl učení považován za stálý, neměnný rys osobnosti, ale je definován jako preference určitého způsobu učení, která se aktuálně mírně mění podle konkrétní situace.

- Modely Paska (Pask, 1976) a Vermunta (Vermunt, 1996) využívají strategie (př́istupy) jako opak stylů, ve kterých zohledňují předchozí zkušenosti a kontextuální vlivy. Strategie jsou založeny na vnímání úkolů a způsobech jejich řešení.

K určení konkrétního stylu učení se nejčastěji používá dotazníková metoda, a to $\mathrm{v}$ kombinaci různých dotazníků (Turek, 2004). Jak z uvedeného přehledu modelů a pojetí vyplývá, je $\mathrm{v}$ současnosti také $\mathrm{k}$ dispozici celá řada dotazníkových metod zjišt'ujících styly učení, jejichž autory jsou představitele výše zmíněných pojetí, ale i další odborníci, např. Biggs, Schmeck, Makarov, Orlov, Entwistle, Gregorc aj. Vyčerpávající popis a charakteristiku nejčastěji využívaných dotazníků pro diagnostiku stylu učení uvádějí publikace J. Mareše (Mareš, 1998) a I. Šimonové (Šimonová, 2010).

Zajímavým př́stupem $\mathrm{k}$ diagnostikování stylu učení dle smyslových preferencí (Fleming, Mills, 1992) představuje klasifikace VARK (akronym slov Visual, Aural, Read/Write, Kinesthetic). Autorem této klasifikace a souvisejícího dotazníku je N. Fleming (Fleming, 1995). Tato klasifikace stylů učení je charakteristická tím, že bere do úvahy to, které smysly percepce student při učení preferuje.

- V znamená VISUAL, tedy vizuálně neverbální. Student $\mathrm{s}$ touto preferencí se nejraději a nejlépe učí, pokud je učivo v obrazové podobě jako obrázky, grafy, schéma, diagramy, mapy, fotografie.

- A znamená AURAL, tedy sluchový styl učení. Student $\mathrm{s}$ tímto stylem učení tedy raději poslouchají a hovoří, než by četli či psali.

- Písmeno R znamená READ/WRITE, česky tedy vizuálně verbální styl učení. Studenti $\mathrm{s}$ touto preferencí se nejlépe a nejraději učí čtením učebních textů.

- K znamená KINESTETIC tedy pohybový učební styl. Studenti s touto preferencí učebního stylu se nejlépe a nejraději učí, pokud mohou $\mathrm{s}$ učivem něco dělat či $\mathrm{s}$ ním 
manipulovat. Jde tedy o takové studenty, kteři chtějí manipulovat, a to i vnitřně, myšlenkově, s objekty i symboly.

Dotazník VARK N. Fleminga obsahuje 13 otázek, které vycházejí z běžných životních situací, nebot' je tato klasifikace určena především pro autodetekci preferovaného stylu učení u dospívajících či dospělých osob - typicky studentů vysokých škol, či účastníků celoživotního vzdělávání (Fleming, 1995). Každá otázka obsahuje 3 nebo 4 nabízené odpovědi a respondent vybere tu odpověd', která nejlépe vystihuje jeho reakci na danou situaci. Dotázaný může vybrat $i$ více možností za předpokladu, že víc odpovědí vystihují jeho reakce. S touto klasifikací stylu učení jsme se poprvé setkali v publikaci I. Turka (Turek, 2004) a již tehdy nás velmi zaujala. S postupem času jsme zjistili, že této problematice je věnována samostatná webová stránka, dostupná volně na adrese: http://www.vark-learn.com, kde je možné nalézt různé jazykové mutace dotazníků, klíčů $\mathrm{k}$ vyhodnocení a ostatních podkladů nutných $\mathrm{k}$ použití této metody diagnostiky tohoto stylu učení.

\section{Možnosti využití stylů učení v elektronickém vzdělávání}

Př́kladem využití aplikace teorie stylů učení do elektronického vzdělávání je systém výukových Webů, které v roce 2004 představil J. Mareš (Mareš, 2004). Návrh tohoto systému vycházel především z článku autorů Rosse a Schulze (Ross, Schulz, 1999), kteří navrhovali přizpůsobit výukový Web (předchůdce dnešního e-learningu) různým stylům učení. $\mathrm{V}$ rámci $\mathrm{Webu}$ adaptujícímu se senzorickým stylům tak Mareš rozlišuje a zdůrazňuje hlavně vizuálni Web (tj. Web, který podporuje vizuální styl učení), který přirozeně nabízel nejvíce vizuálních materiálů (statických textů, obrázků, grafů, animaci, videonahrávek aj.). Auditivni Web (tj. Web, který podporuje auditivní styl učení) měl nabízet především zvukové nahrávky textů či přednášek, hudbu, či diskuze realizované hlasovým přenosem. Jelikož studenti $\mathrm{s}$ kinestetickým (haptickým) stylem učení preferují aktivní práci, praktické prríklady, hledání řešení použitelných v praxi, měl kinestetický Web poskytovat především možnost provádět virtuální nebo vzdálené experimenty, řešit úlohy na principu skládačky apod. I když původní článek vznikl $\mathrm{v}$ roce 1999 a jeho výše uvedená aplikace $\mathrm{v}$ roce 2004, byl jím vytyčen směr, kterým je možné se ubírat i v současnosti. Je také patrné, že koncepce vzdělávacího Webu adaptujícího se senzorickým stylům učení je velmi blízká výše popsané klasifikaci učebních stylů VARK, která byla uplatněna při vytváření samostatných výukových Webů, ze kterých si mohl student vybrat ten, který nejvíce odpovídal jeho preferovanému stylu učení. Pro úplnost je třeba uvést, že J. Mareš ve svém pojednání popsal mimo uvedené Weby adaptující se senzorickým stylům učení i Weby adaptujici se sociálním a kognitivním stylum učení (Mareš, 2004). Dva zbývající typy výukových Webů nejsou, s ohledem na obsah dalšího sdělení, $\mathrm{z}$ našeho pohledu důležité a př́padné zájemce odkazujeme na uvedený primární zdroj. Důležitým aspektem je ale skutečnost, že uvedení autoři ve všech typech výukových Webů doporučovali v maximální míře využívat nového fenoménu té doby - multimédií.

V této souvislosti se tak do popředí zájmu pedagogů dostávaly moderní, na digitálních technologiích postavené elektronické studijní materiály, využívající multimédia (Sokolowsky, Šedivá, 2002). „Multimédia jsou počitačem integrovaná časově závislá nebo časově nezávislá média, která mohou být interaktivně, to znamená individuálně a selektivně vyvolávána či zpracovávána“" (T. Svatoš, in Průcha, 2009). Dle N. a J. Chapmana (Chapman, Chapman 2001) je možné odvodit jednotlivé složky elektronických studijních materiálů, které ,jsou zprostředkovány náročnějšimi technickými sestavami, v nichž má hlavní slovo výpočetni technika - ona jediná je schopna prevést informace z různých zdrojů do společného prostředi procesem nazývaným digitalizace" (Chapman, Chapman, 2001). Multimediální studijní materiály jsou tedy „novým“ typem vzdělávacího materiálu, který obsahuje několik základních složek umožňujících plné využití možností digitálních technologií v edukačním procesu. Základní složky Multimediálního studijního materiálu tvoří (1) hypertext; (2) grafika obrázků; (3) zvuk; (4) video; (5) animace (Chapman, Chapman, 2004) a je ji možné definovat jako: ,jednu znových vzdělávacich technologii, která pro splnění edukačnich záměrů využivá souběžného puisobení pedagogických informaci z různých mediálnich zdrojů, jež jsou záměrně a účelně sjednoceny (obvykle do elektronické podoby) a učicimu člověku interaktivně nabídnuty ke smyslovému vnímání a duševnímu zpracováni" (T. Svatoš, in Průcha, 2009).

Elektronické vzdělávání (zkráceně označované jako e-learning), těchto skutečností v plné míře využilo a postupem času se stalo hojně 
využívaným způsobem výuky a to zejména v distančním vzdělávání. Pojem e-learning, prípadně i jeho kvalita, je ale často rozporuplně vnímán a definován (Eger, 2004). Hlavní prŕćčinou je odlišná terminologie, která je do značené míry ovlivněna jazykovými vlivy a růzností použitých př́stupů i technologií. $\mathrm{V}$ transatlantickém prostoru se pro aktivity spojené s podporou výuky pomocí ICT (e-support) se používá namísto pojmu e-learning (Lowenthal, Wilson, 2009) relativně ustálených pojmů Computer-Based Training (CBT), Internet-Based Training (IBT) nebo Web-Based Training (WBT) (Zounek, 2009). V evropském prostoru existuje konsenzus o použití jednotného pojmu e-learning, který je dle informačního elearningového portálu pro Evropu Elearningeuropa.info chápán jako „aplikace nových multimediálnich technologii a Internetu do vzdéláváni za účelem zvýšeni jeho kvality posilenim pristupu ke zdrojům, službám, k výměně informaci a ke spolupráci" (Šimonová, 2010).

E-learning $\mathrm{v}$ tomto pojetí zahrnuje nejen řadu nástrojů, které slouží pro prezentaci, transfer vzdělávacího obsahu a řízení studia, ale také celé spektrum komunikačních kanálů. Využití nástrojů umožňuje Learning Management System (LMS), který je nezbytným předpokladem pro skutečně efektivní proces vzdělávání s využitím e-learningu. LMS tedy reprezentuje virtuální „učebni'“ prostředí, ve kterém se nacházejí multimediální studijní materiály, zkušební testy, studijní instrukce, cvičební plány nebo diskusní fóra (Mauthe, Thomas, 2004). Základními nástroji realizace e-learningového vzdělávání jsou tak mimo LMS také vhodně strukturované a didakticky uzpůsobené vzdělávací materiály, zkráceně označované jako studijní opory nebo také jako elektronické studijní opory (srov. Paulsen, 2003; Šedá, 2010; Kopecký, 2006). Elektronické studijní opory, využívané v distančním vzdělávání realizovaném formou elearningu mají svá specifika, nebot' jsou určeny pro formu studia, která je charakteristická především vyšší mírou samostatnosti (Bates, Poole, 2003).

3 Elektronické studijní opory využívané v elearningu a jejich struktura

Elektronickou studijní oporu můžeme charakterizovat jako plně elektronický, hypertextový, interaktivni materiál, vytvořený pro realizaci distančního vzděláváni formou e-learningu. Je sestavena tak, aby studentům umožnila snadnou orientaci $\mathrm{v}$ učivu především využitím hypertextového uspořádání textu a využitím širokého spektra multimediálních prvků stimulujících co nejvíce složek studentova vnímání. Elektronická studijní opora by tedy neměla obsahovat pouze nečleněný text, ale i prvky, které upozorn̆ují na důležité pojmy v něm. Text elektronické studijní opory by měl studujícího průběžně motivovat a udržet jeho pozornost obrázky, ale i začleněnými videosekvencemi, zvukovými záznamy apod. Skládá se tedy z hypertextu a dalších prvků, jako jsou např́klad bloky s poznámkami, definicemi a př́klady, které se vkládají př́ímo do hypertextu (jsou zvýrazněny ikonami či margináliemi), a z multimediálních prvků, jež je nutné předem prripravit ve formě souborů či webových destinací. Multimediální prvky se zpravidla ukládají jako objekty do lokálního úložiště a následně se vkládají do vlastního textu elektronického studijního materiálu (Šedá, 2010).

Charakteristickým rysem takto strukturovaných elektronických studijních opor určených pro e-learning je fakt, že jejich struktura je rozšířena o různé multimediální a interaktivní prvky (animace, multimediální záznamy, dynamické simulace, zvukové záznamy apod.). Právě $\mathrm{v}$ tomto rozšiřrení o dynamické interaktivní prvky a multimediální rozšiřrení vidíme hlavní rozdíl elektronických studijních opor určených pro studium formou e-learningu oproti tištěným studijním oporám, určených pro jinou formu distančního vzdělávání. Jejich strukturu vymezil např́klad K. Kopecký (Kopecký, 2006) do tří samostatných skupin strukturálních prvků:

- statické prvky,

- dynamické prvky,

- evaluační a verifikační aparát.

Elektronická studijní opora určená pro distanční vzdělávání formou e-learningu v tomto pojetí představuje funkční spojení textu a multimédií pro dosažení efektivní podpory studia (Kopecký, 2006). Výše uvedené vymezení struktury elektronické studijní opory ale vychází především $\quad z$ charakteru jednotlivých strukturálních prvků, kdy je kladen důraz na jejich statický (text, statická obrazová informace apod.) či dynamický (video, animace, simulace apod.) charakter a nejsou brány $\mathrm{v}$ potaz některé důležité individuální potřeby studenta, které se mohou souviset i se stylem učení. Mimo využití stylů v elektronickém učení jsme v nám dostupných zdrojích nenarazili na typologii strukturálních prvků elektronických studijních 
opor, která zohledňuje styly učení studentů, např́klad dle klasifikace VARK, a která by byla podložena výsledky validního výzkumného šetření.

\section{Záměr, použité metody a popis vzorku realizovaného výzkumného šetření}

Elektronické studijní opory určené pro distanční vzdělávání formou e-learningu se skládají z prvků, které jsou zpravidla děleny na skupinu statických a dynamických. V rámci realizovaného výzkumného šetření jsme se zabývali otázkou, zda jsou všechny tyto prvky stejně potřebné pro různé skupiny studentů, tak, aby co nejlépe respektovaly jejich individualitu, která se projevuje např́klad preferovaným stylem učení dle výše prezentované klasifikace VARK. $\mathrm{Na}$ základě těchto skutečností jsme se rozhodli stanovit výzkumný předpoklad a ověřit jej za pomoci shlukové a faktorové analýzy. Byl tedy stanoven výzkumný předpoklad: rozptyl výsledki $v$ hodnocení jednotlivých strukturálních prvki̊ elektronických studijních opor je možné vysvětlit pomocí faktorů, které jsou ovlivněny preferovaným stylem učení dle klasifikace VARK. Stanovení výzkumného předpokladu postačuje pro prokázání platnosti navržené typologie strukturálních prvků elektronických studijních materiálů na základě preference stylu učení, nebot' se jedná o vhodnou substituci výzkumné hypotézy. Navíc použité metody shlukové a faktorové analýzy často neumožňují sestavení „klasické“ výzkumné hypotézy, nebot' neumožňují zkoumat závislost pouze na dvou množinách proměnných. Výzkumný předpoklad jsme dokazovali pomocí multivariačních (vícerozměrných) statistických metod, shlukové a faktorové analýzy, a to $\mathrm{v}$ souladu s vytyčeným záměrem výzkumného šetření.

Jako základní výzkumná metoda, nutná pro patřičné prokázání stanovaného výzkumného předpokladu, byla použita faktorová analýza (McDonald, 1991), což je statistická metoda používaná $\mathrm{k}$ vydělení důležitých kombinací faktorů $\mathrm{s}$ vysokým stupněm korelace $\mathrm{z}$ velké množiny dat. Faktorová analýza tedy umožňuje najít latentní (nepřímo pozorované) příčiny variability dat. Díky nalezeným latentním proměnným (faktorům) lze redukovat počet proměnných při zachování maxima informací, a je také možné nalézt souvislosti mezi pozorovanými proměnnými a odvozenými faktory. Samostatným problémem faktorové analýzy je tzv. rotace faktorů (StatSoft, 2001). Lze totiž ukázat, že všechny faktorové zátěže, které získáme ortogonální transformací výchozího řešení (násobením matice faktorových zátěží zpravidla ortogonální maticí), mají stejnou schopnost reprodukovat výchozí kovarianční (nebo korelační) matici (Hebák, Hustopecký, 1988). Tuto transformaci nazýváme rotací faktorů, jejímž cílem je získat co nejpřesvědčivějš̌́ vysvětlení jednotlivých faktorů, což bylo nutným předpokladem pro potvrzení či vyvrácení stanoveného výzkumného předpokladu.

Kromě neparametrických testů pro závislé výběry, které jsou určeny pro ordinální proměnné a při nichž je nutno zadávat podobnost proměnných, které chceme zjištovat, existují metody zaměřené na shlukování. Protože je současně zjišt'ována rozdílnost skupin proměnných, jsou v současné literatuře (zejména $\mathrm{v}$ souvislosti $\mathrm{s}$ termínem ,data mining") označovány tyto úlohy jako segmentace (Řezanková, 2010). Proto další výzkumnou metodou, která byla použita při stanovení typologie strukturálních prvků elektronických studijních materiálů na základě stylu učení dle klasifikace VARK, byla shluková analýza (Pecáková, 2008). Shluková analýza patří mezi metody zabývající se zkoumáním podobnosti vícerozměrných objektů (objektů, u nichž je změřeno větší množství proměnných) a jejich roztříděním do skupin (shluků). Uplatňuje se zejména tam, kde objekty projevují prrirozenou tendenci se seskupovat (vznikla jako taxonomická metoda), ale její použití je možné i v dalších oblastech (Meloun, Militký, 2006). Základní př́stup shlukové analýzy je tedy takový, že každý objekt je jednoznačně zařazen do jednoho shluku. Přritom reálné objekty mohou být různého charakteru: shlukovat lze živé organismy, stejně jako textové dokumenty nebo webové stránky (Řezanková, Húsek, Snášel, 2007).

Jako výchozí prostředek pro získání dat potřebných pro realizaci výzkumného šetření byl použit dotazník. Výzkumný dotazník, který byl pro tyto potřeby vytvořen, obsahoval dvě části. První část dotazníku obsahovala 13 otázek a byla zaměřena na zjištění preferovaného stylu učení studenty pomocí standardizované metody VARK. Druhou část dotazníku tvořilo 26 otázek, kdy studenti mohli pomocí hodnotící škály vyjádřit svou preferenci pro jednotlivé strukturální prvky elektronického studijního materiálu. Námi konstruovaný dotazník tedy operoval se dvěma typy dotazníkových otázek. Prvním typem byly otázky alternativní (multiple choice), které byly 
použity pro zjištování učebních stylů z hlediska smyslových preferencí a to plně $v$ souladu s metodou VARK. Druhým typem otázek byly polynomické stupnicové (Horák, Chráska, 1983). Pomocí nich respondenti posuzovali důležitost jednotlivých strukturálních prvků elektronických studijních materiálů podle predem stanované škály. Tato hodnotící škála obsahovala 5 stupňủ, kde číslo 1 znamenalo, že prvek není pro respondenta vůbec důležitý a naopak číslo 5 znamenalo, že tento prvek je pro respondenta velmi důležitý a plně vyhovuje jeho preferenci s ohledem na styl učení.

Výzkumný vzorek tvořilo celkem 354 studentů Pedagogické fakulty Univerzity Palackého v Olomouci, kteří absolvovali výuku v rámci prezenčních i kombinovaných forem studia, prostřednictvím LMS za využití elektronických studijních materiálů určených pro distanční vzdělávání a e-learning. Vybraný výzkumný vzorek odpovídal celkové struktuře studentů realizujících celé studium či část studia distanční formou, nebot' popsané šetření bylo zakomponováno do běžné výuky. Strukturu výzkumného vzorku uvádí následující tabulka číslo 1.

\begin{tabular}{|l|c|c|c|c|c|}
\hline & & & & \\
\hline $\begin{array}{l}\text { preference } \\
\text { stylu }\end{array}$ & 39 & 45 & 90 & 180 & $\mathbf{3 5 4}$ \\
\hline $\begin{array}{l}\text { preference } \\
\text { stylu v \% }\end{array}$ & $11,00 \%$ & $12,70 \%$ & $25,40 \%$ & $50,80 \%$ & $\mathbf{1 0 0 \%}$ \\
\hline $\begin{array}{l}\text { z toho ženy } \\
\text { tylu }\end{array}$ & 33 & 37 & 74 & 102 & $\mathbf{2 4 6}$ \\
\hline $\begin{array}{l}\text { muži } \\
\text { v toho ženy }\end{array}$ & $84,60 \%$ & $82,20 \%$ & $82,20 \%$ & $56,70 \%$ & $\mathbf{6 9 , 5 0 \%}$ \\
\hline $\begin{array}{l}\text { z toho } \\
\text { muži v \% }\end{array}$ & $15,40 \%$ & $17,80 \%$ & $17,80 \%$ & $43,30 \%$ & $\mathbf{3 0 , 5 0 \%}$ \\
\hline $\begin{array}{l}\text { průmérný } \\
\text { věk }\end{array}$ & 19,8 & 20,1 & 20,3 & 24,8 & $\mathbf{2 1 , 2 5}$ \\
\hline
\end{tabular}

Rozložení jednotlivých skupin respondentů podle preference stylu učení za využití klasifikace VARK je samo o sobě překvapivé. I když není cílem této studie podrobně analyzovat jednotlivé skupiny respondentů, je nutné upozornit na několik zajímavých skutečností. První skutečností je, že nejvíce preferovaným stylem je kinestetický čili pohybový styl učení, který preferuje více než $43 \%$ studentů. Ostatní tři styly učení, jsou pak zastoupeny více méně podobně. Druhou skutečností je, že zastoupení mužů i žen $v$ jednotlivých skupinách dle preferovaného stylu učení je stejné a odpovídá celkovému poměru mužů a žen ve vzorku s jednou výjimkou. Touto výjimkou je opět kinestetický styl učení, kde je zastoupení mužů vyšší než u zbývajících tř́i stylů učení.

Výše uvedených skutečností bylo možné využít při analýze získaného výzkumného vzorku, přičemž jej bylo možné rozdělit do skupin podle podobnosti hodnocení jednotlivých strukturálních prvků elektronických studijních materiálů využivaných v e-learningu a to v souvislosti s preferovaným stylem učení studenta dle klasifikace VARK, jak je popsáno v dalším textu předložené studie.

\section{Popis průběhu a výsledků realizovaného výzkumného šetření}

Zvolenou metodou byla provedena prvotní analýza získaných dat, a to na základě použití statistické metody shlukové analýzy (Pošík, 2008). Tuto metodu je možné použít tam, kde se má množina objektů rozdělit na několik relativně stejnorodých skupin, aby se např́klad usnadnila další analýza. Tyto skupiny se nazývají shluky a jejich počet je bud' předem dán, nebo je jeho určení součástí úlohy. Statistické postupy, které jsou pro tento účel vypracovány, se zařazují do tzv. shlukové analýzy (cluster analysis). Shluková analýza je vysoce empirická, proto různé metody shlukování mohou vést $\mathrm{k}$ různým shlukům, popř́padě k různým počtům shluků.

\subsection{Výsledky prvotní shlukové analýzy}

$\mathrm{V}$ této části výzkumu bylo cílem rozdělit sadu strukturálních prvků elektronických studijních materiálů využívaných pro vzdělávání formou elearningu, které reprezentovaly hodnocení charakteristických skupin respondentů z pohledu jejich preferovaného stylu učení dle klasifikace VARK. Tímto způsobem se strukturální prvky elektronických studijních materiálů rozčlenily do skupin, které vykazovaly podobný rozptyl hodnot. Jednoduše řečeno, pokud se vyskytovalo několik strukturálních prvků, které respondenti, s ohledem na preferovaný styl učení, hodnotili velmi podobně, tak tyto prvky vytvořily shluk. Celá situace je patrná $\mathrm{z}$ uvedeného grafu číslo1. 


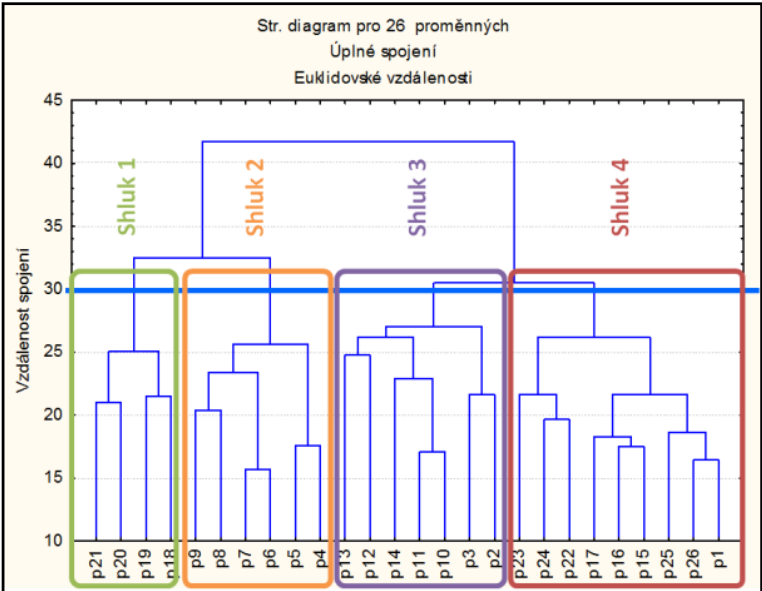

Graf 1- Shluková analýza hodnoceni strukturálnich prvkù elektronických studijnich materialu dle preferovaného stylu učeni

Dle třásňového grafu1, je možné konstatovat, že zkoumané strukturální prvky elektronických studijních materiálů využívaných $\mathrm{v}$ e-learningu, vykazuji výraznou tendenci rozdělovat se do 4 samostatných shlukĭ, které jsou ovlivněny preferovaným stylem učení dle klasifikace $\boldsymbol{V A R K}$. Tuto skutečnost je možné pozorovat na úrovni vzdálenosti spojení pohybující se okolo hodnoty 30 (označena $\mathrm{v}$ obrázku modrou vodorovnou čárou).

\subsection{Ověreni stanoveného výzkumného predpokladu}

Dále byla provedena faktorová analýza. Vzhledem k tomu, že tato metoda je matematicky značně náročná, byl pro vlastní zpracování použit statistický modul Statistica 7.0 (procedura Faktorová analýza) (Blahuš, 1985). Vlastní faktorová analýza byla provedena $\mathrm{s}$ těmito parametry (Blahuš, 1988): Hlavní komponenty rotace - Varimax normalizovaný, za účelem prokázání či odmítnutí stanoveného výzkumného předpokladu. Následující tabulka číslo 2 uvádí, kolik procent rozptylu objasňují jednotlivé extrahované faktory, které představují skupiny strukturálních prvků elektronických studijních materiálů rozdělených dle preferovaného stylu učení dle klasifikace VARK. Celkem bylo těmito 4 faktory objasněno $60,57 \%$ rozptylu.

\begin{tabular}{|c|c|c|c|c|}
\hline \multicolumn{5}{|c|}{ Vlastní č́sla (Spearmanovy korelace); Počet proměnných - } \\
$\mathbf{2 6}$ \\
Extrakce: Hlavni komponenty; Rotace: Varimax normalizovaný \\
\hline & & & \\
& & &
\end{tabular}

\begin{tabular}{|l|l|l|l|l|}
\hline 2 & 4,193476 & 15,2826 & 10,46598 & 37,71531 \\
\hline 3 & 4,037126 & 12,8351 & 14,50311 & 50,55041 \\
\hline 4 & 3,566294 & 10,02421 & 18,0694 & 60,57461 \\
\hline
\end{tabular}

Tabulka 2 - Faktorová analýza hodnocení jednotlivých strukturálních prvků; Vlastní císla a faktory objasněná procenta rozptylu

Na základě provedené faktorové analýzy bylo možné konstatovat: výzkumný předpoklad, že rozptyl výsledků $v$ hodnocení jednotlivých strukturálních prvků elektronických studijních opor je možné vysvětlit pomocí faktorì, které jsou ovlivněny preferovaným stylem učení dle klasifikace VARK bylo možné s přijatelnou mírou rizika přijmout a považovat jej za prokázaný.

\subsection{Interpretace dosažených výsledků}

Výše uvedené výsledky výzkumného šetření ukazují, že studenti $\mathrm{s}$ ohledem na jejich preferovaný styl učení dle klasifikace VARK vidí či rozlišují čtyři skupiny strukturálních prvků elektronických studijních materiálů využívaných ve vzdělávání formou e-learningu, které hodnotí podobně. První skupinu jsme pracovně nazvali, a to na základě charakteristik strukturálních prvků, které obsahuje a které studenti vnímali jako podobné, jako skupinu prvků pro zajištěni navigace ve studiu. Druhou skupinu tvoř́ dynamické prvky zajišst'ující multimedialitu obsahu s výrazným akcentem na interaktivitu obsahu, tady možnosti manipulace s ním. Třetí skupinu tvoří prvky zajišt'ující interaktivitu ve vzdělávání, tedy pro zprostředkování přímé i neprímé komunikace. Poslední čtvrtou skupinu tvoří statické prvky zajišst'ující zprostředkování obsahu. Celou situaci ukazuje níže uvedený graf číslo 2.

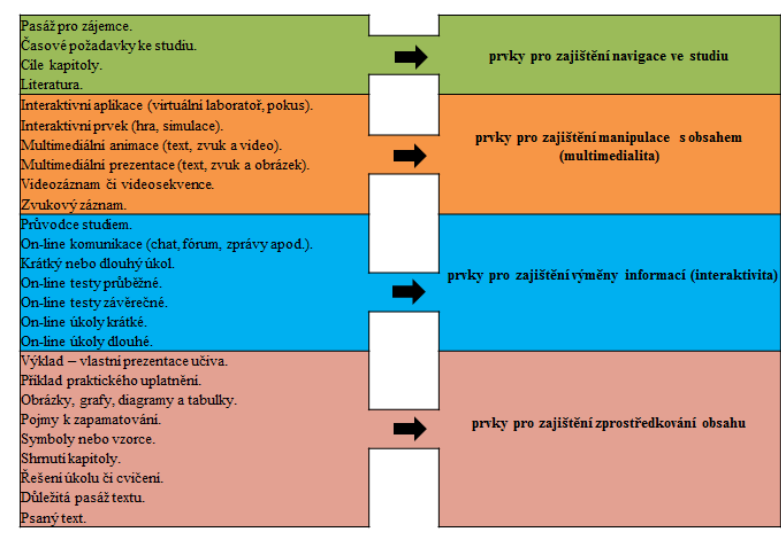

Graf 2 - Nově vymezená typologie strukturálnich prvki̊ elektronických studijnich opor 
Toto rozdělení je použito i v níže uvedeném grafu číslo 3, který znázorňuje, jak vysoko hodnotí jednotlivé skupiny studentů rozdělené podle preferovaného stylu učení dle klasifikace VARK (v grafu jsou znázorněny různými barvami), jednotlivé skupiny strukturálních prvků dle námi vytvořené typologie.

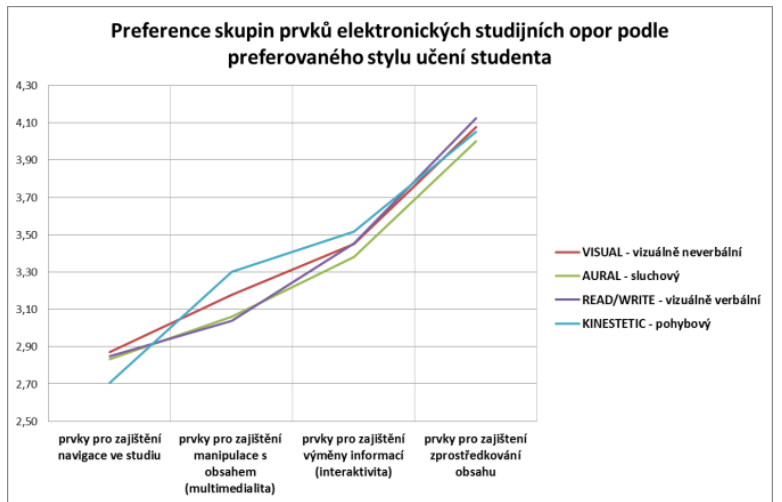

Graf 2 - Hodnoceni skupin strukturálnich prvkü elektronických studijnich materiálù dle preferovaného stylu učeni dle klasifikace VARK

Je vidět, že všechny skupiny studentů, bez rozdílu preference stylu učení, vysoce hodnotí statické prvky pro zajištění zprostředkování obsahu, kam patří např́iklad., shrnutí kapitoly, důležitá pasáž textu, pojmy $\mathrm{k}$ zapamatování apod. Snaha o dobrou prezentaci obsahu je tak z pohledu studentů vnímána jako nejdůležitější.

Podobná situace, mimo pořadí, je i u skupiny strukturálních prvků zajišt'ující interaktivitu ve smyslu zprostřredkování komunikace. Studenti tedy vnímají, a to bez rozdílu v preferenci učebního stylu, komunikaci jako druhý nejdůležitější prvek.

Významné rozdíly je ale možné vidět u skupiny dynamických prvků zajištujících multimedialitu obsahu s výrazným akcentem na možnost manipulace s obsahem, kde je výrazný rozdíl v hodnocení u skupiny studentů preferujících pohybový či kinestetický styl učení, což se ale dalo čekat, nebot' mají v povaze experimentovat a manipulovat s učivem. Co je ale neočekávané, je to, Neočekávané je, že u skupiny studentů preferujících vizuálně verbální styl učení je to naopak. I když je tato skupina studentů charakteristická tím, že se nejraději učí čtením a pozorováním, což multimédia dobře umožňují, vadí jim zřejmě nutnost manipulace s obsahem a preferují multimediální prvky bez interaktivní složky. Podobná situace je také u skupiny studentů preferující sluchový styl učení, kteří zřejmě také zjevnou činnost tolik nepreferují.
U poslední skupiny strukturálních prvků zajišt'ujících navigaci ve studiu jsme v zásadě pozitivně hodnotili, že dle zjištěných výsledků nejsou tyto prvky u vysokoškolských studentů výrazně preferované, nebot' se zrrejmě dovedou $\mathrm{v}$ textu i rozložení studia zorientovat samostatně. Je to důležité při studiu nestrukturalizovaných texti̊, např́klad vědeckých publikací, a pro vysokoškolské studium důležité.

\section{Závěr}

Na základě uvedených výsledků realizovaného výzkumného šetření je možné vymezit novou typologii strukturálních prvků elektronických studijních materiálů využivaných v distančním vzdělávání realizovaným formou e-learningu. Tato typologie, zohledňuje jeden $\mathrm{z}$ důležitých př́stupů ke klasifikaci stylů učení dle preference smyslového vnímání. $\mathrm{Z}$ tohoto pohledu je tedy možné strukturální prvky těchto materiálů rozdělit do čtyř samostatných skupin:

- skupinu prvků pro zajištění navigace ve studiu,

- skupinu prvků zajištující multimedialitu obsahu,

- skupinu prvků zajišt'ujících interaktivitu ve vzdělávání,

- skupinu statických prvků zajišt'ující zprostředkování obsahu.

$\mathrm{V}$ současnosti objevují i názory, jako např. Lewis a Orton (Sak, Mareš, 2007), které označují různé styly za mýtus, jenž je třeba zbavit falešného pozlátka, a kladou větší důraz na pojem „strategie učení“ (Mareš, 1998). S tímto názorem se neztotožňujeme, nebot' styly učení považujeme za významnou determinantu efektivního vzdělávání. Respektováním stylů učení v plně elektronickém způsobu vzdělávání, jaké dnes představuje e-learning, je možná nová kvalita umožňující hodnotnou prezentaci obsahu, adekvátní interakci a také komfort pro studující doposud nevídaný. Toto spojení je třeba soustavně studovat a hledat nové př́stupy, které by umožnily danou oblast dále rozvinout a formulovat principy umožňující hlubší interakci studenta s výukovým obsahem. To informační a komunikační technologie na soudobé úrovni zabezpečují již dobře, pokud ovšem uplatnění pedagogických hledisek je cílevědomé.

\section{Literatura}

[1] BATES, A., POOLE, G. (2003). Effective Teaching with Technology in Higher Education. 1. vyd., San Francisco: Jossey-Bass/John Wiley, 2003. $305 \mathrm{~s}$. 
[2] BLAHUŠ, P. Faktorová analýza a jeji zobecnění. 1. vyd., Praha, 1985. 451 s.

[3] BLAHUŠ, P. K metodologii použiti statistických metod v psychologii. 1. vyd., Praha, 1988. $214 \mathrm{~s}$.

[4] BRIGGS-MYERS, I., BRIGGS, K. C. MyersBriggs Type Indicator (MBTI). 1. vyd., Palo Alto, CA: Consulting Psychologists Press, 1985. $154 \mathrm{~s}$. [5] COFFIELD, F. et al. Learning styles and pedagogy in post-16 learning. A systematic and critical review. Newcatle University report on learning styles [online]. Newcatle, 2004 [cit. 2013-04-21]. Dostupné z WWW: <http://www.Isda.org.uk/files/PDF/1543.pdf>.

[6] CURRY, L. One critique of the research on learning styles. Studies in Educational Leadership. 1990, 48, 2, s. 50-56.

[7] DUNN, R. The Dunn and Dunn learning style model and research. 3. vyd., New York: St John's University, 2003. 214 s.

[8] EGER, L. Evaluace e-learningu se zaměřením na pedagogickou stránku. Studie in E-learning prípadová studie z projektu Comenius. Plzeň: ZČÚ Plzeň, 2004. 74 s. ISBN 80-7043-265-9.

[9] FELDER, F. M., SILVERMAN, L. K. Learning/Teaching styles in engineering education. Studies in Journal of engineering education. 1998, 78, 8. s. 674-681.

[10] FLEMING, N. D. I'm different; not dumb. Modes of presentation (VARK) in the tertiary classroom. Studies in Zelmer, A., (Ed.) Research and Development in Higher Education, Proceedings of the 1995 Annual Conference of the Higher Education and Research Development Society of Australasia, HERDSA. 1995, 18. s. $308-313$.

[11] FLEMING, N. D., MILLS, C. Not Another Inventory, Rather a Catalyst for Reflection. Studies in Improve the Academy. 1992, 11, 1. s. 137-155.

[12] GARDNER, H. Heteroglossia: A Global Perspective. Studies in Interdisciplinary Journal of Theory of Postpedagogical Studies. 1984, 12, 2. s. 34-45.

[13] GARDNER, H. How Are Kids Smart: Multiple Intelligences in the Classroom. 1. vyd., National Professional Resources, Gloucester: MA, $1995.89 \mathrm{~s}$.

[14] HEBÁK, P., HUSTOPECKÝ, J. Statistická analýza vícerozmérných dat. Praha: SNTL, 1988. $158 \mathrm{~s}$.

[15] HONEY, P., MUMFORD, A. Using your learning styles. 1. vyd., Maidenhead: Peter Honey Publications, 2002. 325 s.
[16] HORÁK, F., CHRÁSKA, M. Metodologie pedagogiky. 1. vyd., Olomouc: Vydavatelství Univerzity Palackého, 1983. 147 s.

[17] CHAPMAN, N., CHAPMAN, J. Digital Multimedia. 1. vyd., Boston: Addison-Wesley, 2001. $143 \mathrm{~s}$.

[18] CHAPMAN, N., CHAPMAN, J. Digital Multimedia 3. vyd., Mississauga: John Wiley \& Sons, 2004. $232 \mathrm{~s}$.

[19] KOLB, A. D. Experiential learning: experience as the source of learning and development. 1. vyd., Englewood Cliffs, New Jersey: Prentice Hall, 1984. 169 s.

[20] KOPECKÝ, K. E-learning (nejen) pro pedagogy. 1. vyd., Olomouc: Hanex, 2006. $121 \mathrm{~s}$. ISBN 80-85783-50-9.

[21] LOWENTHAL, P. R., WILSON, B. A description and typology of the online learning landscape. Studies in M. Simonson (Ed.), 32nd Annual proceedings: Selected research and development papers presented at the annual convention of the Association for Educational Communications and Technology [online]. Washington D. C.: Association for Educational Communications and Technology, 2009. [cit. 2013-3-14]. Dostupné z WWW:

<http://www.patricklowenthal.com/publications/ AECT2009TypologyOnlineLearning.pdf >

[22] MARES̆, J. (1998) Styly učení žákì a studentì. 1. vyd., Praha: Portál. ISBN 80-7178246-7.

[23] MAREŠ, J. E-learning a individualní styly učení. Studie in Československá psychologie. 2004 ,48, 3, s. 247-262.

[24] MARSHALL J. C. (1987) Examination of a Learning Style Topology. Studies in Research in Higher Education. New York: Springer. 1987, 26, 4, s. 417-429.

[25] MAUTHE, A., THOMAS, P. Professional Content Management Systems: Handling Digital Media Asset. 2. vyd., New York: John Wiley \& Sons, 2004. $157 \mathrm{~s}$.

[26] McDONALD, R., P. Faktorová analyza a př́buzné metody v psychologii. 1. vyd., Praha: Academia, 1991, 256 s. ISBN 80-200-0081-X.

[27] MELOUN, M., MILITKÝ, J. Kompendium statistického zpracování dat: metody a řešené úlohy. 2. přepracované a rozšířené vyd., Praha: Academia, 2006. 982 s. ISBN: 80-200-1396-2.

[28] MITCHELL, D. P. (1994) Learning style: a critical analysis of the concept and its assessment. 2. vyd., London: Kogan Page, 1994. $225 \mathrm{~s}$. 
[29] PASK, G. Styles and strategies of learning. Studies in British journal of educational psychology. 1976, 46, 1, s. 128-148.

[30] PAULSEN, M. F. Online Education and Learning Management Systems - Global Elearning in a Scandinavian Perspective (1th. ed.). 1. vyd., Oslo: NKI Forlaget, 2007. $71 \mathrm{~s}$.

[31] PECÁKOVÁ, I. Statistika $v$ terénnich prizkumech. 1. vyd., Praha: Professional Publishing, 2008. 231 s. ISBN 978-80-86946-740 .

[32] POŠÍK, P. Jak na data mining v programu STATISTICA Data Miner. 1. vyd., Praha: StatSoft, 2008. 78 s. ISBN 978-80-903630-6-9.

[33] PRŮCHA, J. Pedagogická encyklopedie. 1. vyd., Praha: Portál, 2009. 936 s. ISBN 978-807367-546-2.

[34] RIDING, R. J., CHEEMA, I. Cognitive styles - an overview and integration. Studies in Educational psychology. 199, 11, 3-4, s. 193-215. Ross, J. L., \& Schulz, R. A. Using the World Wide Web to Accommodate Diverse Learning Styles. Studies in College Teaching. 1999, 47, 4, s. $120-128$.

[35] ŘEZANKOVÁ, H. Analýza dat $z$ dotaznikových šetření. 2. vyd., Praha: Professional Publishing, 2010. 217 s. ISBN: 97880-7431-019-5.

[36] ŘEZANKOVÁ, H., HÚSEK, D., SNÁŠEL, V. Shluková analýza dat. 1. vyd., Praha: Professional Publishing, 2007, 196 s. 978-8086946-26-9.

[37] SAK, P., MAREŠ, J. et al. Člověk a vzděláni $v$ informační společnosti. 1. vyd., Praha: Portál, 2007. 290 s. ISBN 978-80-7367-230-0.

[38] SOKOLOWSKY, P., ŠEDIVÁ, Z Multimédia - současnost budoucnosti. 1. vyd., Praha: Grada, 1994. 118 s.

[39] STATSOFT Statistica 6.0 ve vašem městě: sbornik $k$ cyklu prezentaci nové generace programu. Praha: StatSoft, 2001. ISBN 80-2387593-0.

[40] ŠEDÁ, J. Elearning - tvorba studijnich opor [online]. VŠE Praha: Integrovaný informační systém, 2010. [cit. 2013-4-1]. Dostupné z WWW:

$<$ http://isis.vse.cz/dok_server/slozka.pl?id=51;do wnload $=81>$.

[41] ŠIMONOVÁ, I. et al. Styly učeni $v$ aplikacích eLearningu. 1. vyd., Hradec Králové: M\&V, 2010. 116 s. ISBN 978-80-86771-44-1.

[42] TUREK, I. Inovácie v didaktike. 2. vyd., Bratislava: Metodicko-pedagogické centrum, 2005. 360 s. ISBN 80-8052-230-8.

[43] VERMUNT, J. D. Metacognitive, cognitive and affective aspects of learning styles and strategies: a phenomenographic analysis. Studie $s$ in Higher education. 1996, 31, 1, s. 25-50.

[44] ZOUNEK, J. E-learning - jedna z podob učeni $v$ moderni společnosti. 1. vyd., Brno: Masarykova univerzita, 2009. 161 s. ISBN 97880-210-5123-2.

doc. PhDr. Milan Klement, Ph.D.

Katedra technické a informační výchovy

Pedagogická fakulta UP

Žižkovo nám. č. 5

77140 Olomouc, ČR

Tel: +420 585635811

E-mail: milan.klement@upol.cz

Www pracoviště: www.kteiv.upol.cz

PaedDr. PhDr. Jiř́i Dostál, Ph.D.

Katedra technické a informační výchovy

Pedagogická fakulta UP

Žižkovo nám. č. 5

77140 Olomouc, $\check{C} R$

Tel: +420 585635813

E-mail: j.dostal@upol.cz

Www pracoviště: www.kteiv.upol.cz 